ISSN 2615-3939

IAIN Kudus

http://journal.stainkudus.ac.id/index.php/jmtk

\title{
PENGARUH PEMBELAJARAN 5 HARI SEKOLAH TERHADAP \\ PRESTASI BELAJAR MATEMATIKA PESERTA DIDIK \\ SMA NEGERI 1 BAE KUDUS
}

\author{
Sugihardjo \\ SMA Negeri 1 Bae Kudus \\ gihardjosabaku03@gmail.com
}

\begin{abstract}
Abstrak: Penelitian ini bertujuan (1) untuk mengetahui pengaruh pembelajaran 5 hari sekolah terhadap prestasi belajar matematika peserta didik dan (2) untuk mengetahui seberapa besar pengaruh pembelajaran 5 hari sekolah terhadap prestasi belajar matematika.

Penelitian dilaksanakan pada semsester ganjil tahun pelajaran 2018/2019, dengan jenis penelitian deskriptif kuantitatif. Populasi dalam penelitian ini adalah seluruh peserta didik SMA Negeri 1 Bae Kudus, dengan cacah sampel 137 peserta didik. Analisis data menggunakan uji $\mathrm{t}$-test beda rerata untuk data berpasangan, dengan taraf signifikansi $\alpha=0,05$. Kesimpulan dari penelitian ini adalah: (1) terdapat pengaruh pembelajaran 5 hari sekolah terhadap prestasi belajar matematika peserta didik, hal ini ditunjukkan dengan nilai $\mathrm{t}_{\text {hit }}=-17,429$ dan $\mathrm{DK}=\{\mathrm{t} \mid \mathrm{t}<-1,656$ atau $\mathrm{t}$ $>1,656$ \}, ternyata $t_{\text {hit }} \in$ DK sehingga $\mathrm{H}_{0}$ ditolak. (2) Hasil perhitungan koefisien determinasi $\left(\mathrm{r}^{2}\right)$ sebesar 0,111 artinya besarnya pengaruh 5 hari sekolah terhadap prestasi belajar matematika sebesar $11,1 \%$, dan diperoleh koefisien korelasi (r) sebesar 0,334 dengan interpretasi korelasinya berkategori lemah, artinya pembelajaran 5 hari sekolah bukan satu - satunya faktor yang menentukan prestasi belajar matematika peserta didik melainkan adanya faktor - faktor lain yang tidak ada di dalam penelitian ini.
\end{abstract}

Kata Kunci: 5 Hari Sekolah, Prestasi Belajar, Prestasi Belajar Matematika

\begin{abstract}
This study aims (1) to determine the effect of learning 5 school days on students' mathematics learning achievement and (2) to find out how much influence 5-day school learning has on mathematics learning achievement.

The study was conducted in the odd semester of the 2018/2019 school year, with a type of quantitative descriptive research. The population in this study were all students of SMA Negeri 1 Bae Kudus, with a sample of 137 students. Data analysis using t-test mean difference for paired data, with a significance level $\alpha=0.05$. The conclusions of this study are: (1) there is an effect of learning 5 school days on students' mathematics learning achievement, this is indicated by $t_{\mathrm{obs}}=-17,429$ and $\mathrm{DK}=\{\mathrm{t} \mid \mathrm{t}<-1,656$ or $\mathrm{t}>1,656\}$, it turns out thit $\in \mathrm{DK}$ so $\mathrm{H}_{0}$ is rejected. (2) The results of the calculation of the coefficient of determination $\left(\mathrm{r}^{2}\right)$ is 0.111 , meaning the magnitude of the influence of 5 school days on mathematics learning achievement is $11.1 \%$, and the correlation coefficient (r) is 0.334 and the correlation interpretation is weak. It means that 5 days school is not the only factors that determine students' mathematics learning achievement but other factors that are not present in this study.
\end{abstract}

Keywords: 5 Days School, Learning Achievement, Mathemathics Learning Achievement 


\section{PENDAHULUAN}

Sumber daya manusia (SDM) yang berkualitas dan bermutu merupakan pilar utama dalam pembangunan suatu bangsa, untuk meningkatkan kualitas dan mutu SDM dapat dilakukan dengan cara peningkatan mutu pendidikan. Pendidikan merupakan hal yang penting bagi setiap individu karena dengan pendidikan manusia akan memperoleh kesejahteraan di dalam hidupnya.

Salah satu upaya yang dilakukan pemerintah untuk meningkatkan mutu pendidikan adalah dengan mengeluarkan kebijakan - kebijakan baru yang dapat memperbaiki bahkan meningkatkan mutu pendidikan. Salah satu kebijakan yang dikeluarkan adalah Peraturan Menteri Pendidikan dan Kebudayaan (Permendikbud) Nomor 23 tahun 2017 tentang Hari Sekolah, pasal 2 peraturan tersebut mengatur bahwa hari sekolah dilaksanakan 8 jam dalam 1 hari atau 40 jam selama 5 hari dalam 1 minggu.

Dengan bergulirnya Permendikbud tersebut banyak menuai polemik, ada yang mendukung, namun tak sedikit yang menolak. Polemik ini perlu ditelaah secara objektif dan rasional demi peningkatan kualitas pendidikan nasional. Pihak pro adalah mereka yang menerima rasionalisasi yang diberikan oleh Mendikbud sebagai pencetus ide. Di sisi lain, mereka yang kontra merupakan pihak yang tidak menerima dengan rasionalisasi yang dilakukan Mendikbud karena menemukan berbagai hal yang dianggap ganjil dan tidak masuk akal, sehingga lebih memilih tetap dengan sistem sekolah setengah hari.

Pihak yang kontra berpendapat bahwa dampak dari pelaksanaan permendikbud ini, mengakibatkan kondisi fisik peserta didik yang lelah, letih, dan kurang semangat dalam mengikuti pelajaran, sehingga dapat mengganggu konsentrasi belajar peserta didik serta tidak jarang kondisi belajar tidak efektif. Hal ini tentunya sangat memberikan pengaruh terhadap prestasi belajar peserta didik, yang dimungkinkan prestasi belajar menurun.

Meskipun terjadi pro - kontra mengenai pembelajaran 5 hari sekolah, SMA Negeri 1 Bae tetap melaksanakan program "5 Hari Sekolah" sejak tahun pelajaran 2017/2018, program tersebut dapat berjalan dengan lancar karena tersedianya sarana dan prasarana yang memadai serta adanya dukungan dari warga sekolah. Untuk mengetahui reaksi warga sekolah dengan pelaksanaan 5 hari sekolah, maka 
pihak sekolah mengedarkan angket yang berkaitan dengan pelaksanaan 5 hari sekolah di SMA Negeri 1 Be Kudus. Angket yang diedarkan sebanyak 1294 angket, angket yang kembali 1211 (93,59\%) dengan hasil $1070(88,36 \%)$ setuju pelaksanaan 5 hari sekolah, $131(10,82 \%)$ tidak setuju, dan $10(0,83 \%)$ angket rusak. Kenyataan di lapangan, pernyataan dari pihak kontra bahwa peserta didik lelah, letih, dan ditambah mengantuk saat pembelajaran berlangsung juga ditemui di SMA Negeri 1 Bae.

Peneliti tertarik untuk meneliti apakah ada pengaruh pembelajaran 5 hari sekolah di SMA Negeri 1 Bae terhadap prestasi belajar peserta didik khususnya mata pelajaran matematika. Penelitian ini difokuskan pada mata pelajaran matematika karena peneliti adalah guru matematika dan matematika sebagai salah satu mata pelajaran yang membutuhkan daya konsentrasi tinggi, bisa jadi dengan pelaksanaan 5 hari sekolah peserta didik terganggu proses pembelajarannya.

Berdasarkan latar belakang masalah di atas maka rumusan masalah dalam penelitian ini adalah

a. manakah yang menghasilkan prestasi belajar matematika yang lebih baik peserta didik yang dikenai pembelajaran 5 hari sekolah atau peserta didik yang dikenai pembelajaran 6 hari sekolah?

b. seberapa besar pengaruh pembelajaran 5 hari sekolah terhadap prestasi belajar matematika?

\section{METODE}

Penelitian ini dilaksanakan di SMA Negeri 1 Bae Kudus dengan subjek penelitian adalah seluruh peserta didik semester gasal tahun pelajaran 2017/2018. Penelitian dilaksanakan pada semester gasal tahun pelajaran 2017/2018.

Populasi penelitian ini adalah peserta didik SMA negeri 1 Bae Kudus semseter gasal tahun pelajaran 2017/2018. Adapun sampel dalam penelitian ini adalah peserta didik kelas XI peminatan IPS. Teknik pengambilan sampel dilakukan dengan random sampling.

Dalam penelitian ini terdapat satu variabel bebas yaitu pembelajaran 5 hari sekolah dan satu variabel terikat yaitu prestasi belajar matematika. Teknik pengambilan data yang digunakan adalah metode dokumentasi. Metode 
dokumentasi digunakan untuk mengambil data nilai penilaian akhir semester ganjil 2017/2018 untuk uji keseimbangan, serta nilai pengetahuan mata pelajaran matematika pada raport semester genap tahun pelajaran 2016/2017 dan nilai pengetahuan mata pelajaran matematika semester ganjil tahun pelajaran 2017/2018 untuk mengumpulkan data mengenai prestasi belajar.

Untuk menguji apakah data yang diperoleh berasal dari populasi berdistribusi normal atau tidak maka digunakan uji normalitas, dalam penelitian ini uji normalitas yang digunakan adalah metode Lilliefors. Sedangkan untuk menguji apakah populasi mempunyai variansi yang sama, metode yang digunakan adalah metode Barlett.

Pengujian hipotesis pada penelitian menggunakan uji $t$ - test data berpasangan, tujuan untuk menguji manakah yang menghasilkan prestasi lebih baik pembelajaran 5 hari sekolah atau pembelajaran 6 hari sekolah. Tindak lanjut dari uji $\mathrm{t}$ - test jika $\mathrm{H}_{0}$ ditolak, menghitung seberapa besar pengaruhnya terhadap prestasi belajar matematika peserta didik dengan menghitung koefisien determinasi $\left(\mathrm{r}^{2}\right)$.

Perhitungan uji $\mathrm{t}$ - test pada penelitian ini menggunakan perhitungan “Analysis ToolPak” pada Microsoft Office Excel dan menggunakan rumus

$$
t=\frac{\bar{D}-d_{0}}{\frac{s_{d}}{\sqrt{n}}} \sim t(n-1) \text { dengan } D=X-Y
$$

(Budiyono, 2009: 151)

Sedangkan untuk perhitungan koefisien determinasi $\left(\mathrm{r}^{2}\right)$ juga menggunakan perhitungan "Analysis ToolPak" pada Microsoft Office Excel dan menggunakan rumus $r^{2}=\frac{J K R}{J K G}$ besarnya $\mathrm{r}^{2}$ yaitu $0 \leq \mathrm{r}^{2} \leq 1$ (Budiyono, 2009: 258). Besaran interpretasi koefisien korelasi dapat mengacu pada pedoman berikut:

Tabel 1 Interpretasi Koefisien Korelasi

\begin{tabular}{cc}
\hline Nilai Korelasi (r) & Interpretasi Korelasi \\
\hline $0,00-0,190$ & Sangat Lemah \\
$0,20-0,399$ & Lemah \\
$0,40-0,599$ & Sedang \\
$0,60-0,799$ & Kuat \\
\hline
\end{tabular}




$0,80-1,000 \quad$ Sangat Kuat

(Sugiyono, 2014)

Statik uji yang digunakan untuk uji keseimbangan adalah anava satu jalan dengan sel sama, yang diasumsikan memenuhi normalitas dan homogenitas. Untuk perhitungan anava satu jalan menggunakan perhitungan "Analysis ToolPak” pada Microsoft Office Excel dan perhitungan menggunakan rumus $F_{\text {obs }}=\frac{R K A}{R K G}$ (Budiyono, 2009:196-198).

\section{HASIL DAN PEMBAHASAN}

Penelitian ini perhitungan uji normalitas dilakukan dengan menggunkan metode Lilliefors dengan taraf signifikansi 0,05. Hasil uji normalitas seperti terangkum dalam Taabel 2 berikut

Tabel 2 Rangkuman Hasil Uji Normalitas

\begin{tabular}{cccccc}
\hline Perlakuan & $\mathrm{n}$ & $L_{\text {obs }}$ & $L_{\text {tabel }}$ & $\begin{array}{c}\text { Keputusan } \\
\text { Uji }\end{array}$ & Kesimpulan \\
\hline 6 hari sekolah & 137 & 0,0678 & 0,0757 & $\mathrm{H}_{0}$ diterima & Normal \\
5 hari sekolah & 137 & 0,0631 & 0,0757 & $\mathrm{H}_{0}$ diterima & Normal \\
\hline
\end{tabular}

Berdasarkan hasil uji normalitas tampak bahwa bahwa nilai $\mathrm{L}_{\mathrm{obs}}$ untuk setiap perlakuan kurang dari $\mathrm{L}_{\text {tabel }}\left(\mathrm{L}_{\text {obs }} \notin \mathrm{DK}\right)$. Hal ini berarti bahwa pada taraf signifikansi 0,05 hupotesisnol (H0) untuk setiap perlakuan diterima. Dengan demikian dapat disimpulkan bahwa sampel dalam penelitian ini berasal dari populasi yang berdisribusi normal.

Dari hasil uji homogenitas variansi populasi diperoleh nilai $\chi_{o b s}^{2}$ sebesar 0,3596 kurang dari nilai $\chi_{0,05 ; 1}^{2}$ sebesar 3,8410 ( $\left.\chi_{o b s}^{2} \notin \mathrm{DK}\right)$. Hal ini berarti pada taraf signifikansi 0,05 hipotesis nol $\left(\mathrm{H}_{0}\right)$ diterima, sehingga dapat disimpulkan bahwa populasi yang dibandingkan mempunyai variansi yang sama (homogen).

Perhitungan uji keseimbangan dalam penelitian ini menggunakan analisi variansi dengan taraf signifikansi 0,05, rangkuman hasil uji keseimbangan disajikan dalam Tabel 3 berikut: 
Tabel 3 Rangkuman Hasil Uji Keseimbangan

\begin{tabular}{|c|c|c|c|c|c|c|}
\hline Sumber & $\mathrm{JK}$ & $\mathrm{dk}$ & RK & $\mathrm{F}_{\text {obs }}$ & $\mathrm{F}_{\alpha}$ & Keputusan \\
\hline Perlakuan & 1,46 & 1 & 1,460 & 0,029 & 3,876 & $\mathrm{H}_{0}$ diterima \\
\hline Galat & 13708,49 & 272 & 50,399 & - & - & \\
\hline Total & 13709,95 & 273 & - & - & - & \\
\hline
\end{tabular}

Berdasarkan hasil uji keseimbangan diperoleh nilai $\mathrm{F}_{\mathrm{obs}}$ sebesar 0,029 dan $\mathrm{F}_{\alpha}$ sebesar 3,876 dengan $\mathrm{DK}=\{F \mid F>3,876\}$ sehingga $\mathrm{F}_{\text {obs }}$ berada di luar daerah kritik. Hal ini berarti pada taraf signifikansi 0,05, keputusan uji keseimbangan adalah $\mathrm{H}_{0}$ doterima. Dengan demikian diperoleh bahwa populasi mempunyai kemampuan awal yang sama.

Pada penelitian ini data yang digunakan dalam pengujian hipotesis dengan uji $\mathrm{t}$ - test adalah data prestasi belajar matematika (nilai pengetahuan pada raport kelas X semester genap tahun pelajaran 2016/2017 masih dengan pembelajaran 6 hari sekolah dan nilai pengetahuan pada raport kelas XI semester ganjil tahun pelajaran 2017/2018 sudah dilaksanakan pembelajaran 5 hari sekolah), hasil komputasi ujinya dapat dilihat pada Tabel 4,

Tabel 4 Uji t - test Beda Rerata Data Berpasangan

\begin{tabular}{lrr}
\hline & \multicolumn{2}{c}{ Nilai Pengetahuan Raport } \\
& 6 hari Sekolah & 5 hari sekolah \\
\hline Rerata & 77,400 & 83,759 \\
Variansi & 7,893 & 18,383 \\
Cacah & 137 & 137 \\
$\mathrm{~d}_{0}$ & 0 & \\
$\mathrm{Dk}$ & 136 & \\
$\mathrm{t}_{\text {obs }}$ & $-17,429$ & \\
$\mathrm{t}_{\text {tabel }}$ & 1,656 & \\
Keputusan $\mathrm{Uji}$ & $\mathrm{H}_{0}$ ditolak \\
\hline
\end{tabular}

Berdasarkan Tabel 4 dapat disimpulkan bahwa nilai $\mathrm{t}_{\mathrm{obs}}=-17,429$ dan $\mathrm{DK}=$ $\{\mathrm{t} \mid \mathrm{t}<-1,656$ atau $\mathrm{t}>1,656\}$, ternyata $\mathrm{t}_{\mathrm{obs}} \in \mathrm{DK}$ sehingga $\mathrm{H}_{0}$ ditolak. Hal ini 
berarti bahwa terdapat prestasi belajar peserta didik yang dikenai pembelajaran 5 hari sekolah lebih baik daripada peserta didik yang dikenai pembelajaran 6 hari sekolah, sehingga dapat dikatakan terdapat pengaruh pembelajaran 5 hari sekolah terhadap prestasi belajar matematika peserta didik.

Selanjutnya dilakukan perhitungan untuk mengetahui seberapa besar pengaruh pembelajaran 5 hari sekolah terhadap prestasi belajar matematika. Rangkuman hasil perhitungan koefisien determinasi $\left(r^{2}\right)$ dan interpretasi korelasi $(r)$ disajikan pada Tabel 5 berikut: 
Tabel 5 Koefisien Determinasi $\left(\mathrm{r}^{2}\right)$ dan Interpretasi Korelasi (r)

\begin{tabular}{lr}
\hline \multicolumn{2}{c}{ Regresi dan Korelasi Linear } \\
\hline Interpretasi Korelasi $(\mathrm{r})$ & 0,334 \\
Koefisien Determinasi $\left(\mathrm{r}^{2}\right)$ & 0,111 \\
Kesalahan Baku taksiran $\left(\mathrm{s}_{\mathrm{yx}}\right)$ & 4,057 \\
Cacah $(\mathrm{n})$ & 137 \\
\hline
\end{tabular}

Berdasarkan Tabel 5 bahwa koefisien determinasi $\left(r^{2}\right)$ sebesar 0,111 menunjukkan besarnya pengaruh 5 hari sekolah terhadap prestasi belajar matematika sebesar 11,1\%. Dengan koefisien korelasi (r) sebesar 0,334 yang berkategori lemah.

Hari sekolah adalah jumlah hari dan jam yang digunakan oleh guru, tenaga kependidikan, dan peserta didik dalam penyelenggaraan pendidikan di sekolah. Lebih lanjut dalam pasal 2 disebutkan bahwa "Hari sekolah dilaksanakan 8 (delapan) jam dalam 1 (satu) hari atau 40 (empat puluh) jam selama 5 (lima) hari dalam 1 (satu) minggu. Sesuai dengan pasal 8 bahwa "Penetapan Hari Sekolah sebagaimana dimaksud dalam pasal 2 dilaksanakan pada tahun pelajaran 2017/2018. (Permendikbud No. 23 tahun 2017)

Matematika terdiri atas empat kawasan yang luas yaitu aritmatika, aljabar, geometri, dan anlisis. Seringkali matematika disebut sebagai ratunya ilmu, hal ini dikarenakan matematika tidak tergantung pada bidang studi yang lain. Matematika adalah bahasa simbolis yang fungsi praktiknya untuk mengekspresikan hubungan hubungan kuantitatif dan keruangan, sedangkan fungsi teoritisnya adalah untuk memudahkan berpikir. Ciri utama matematika adalah penggunaan cara bernalar deduktif, tetapi juga tidak melupkana cara bernalar induktif. Matematika selain sebagai bahasa simbolis juga merupakan bahasa universal yang memungkinkan manusia memikirkan, mencatat, dan mengkomunikasikan ide mengenai elemen dan kuantitas.

Depdiknas (2004: 2) mendefinisikan matematika sekolah dengan pengertian bahwa materi dan pola pikirnya telah dipilih dan disesuaikan dengan proses perkembangan peserta didik. Meskipun objek matematika adalah abstrak, namun pengajarannya dapat dimulai dari objek yang kongkrit. Selain itu matematika 
sekolah juga disesuaikan dengan kebutuhan penerapannya dalam kehidupan sehari - hari dan perkembangan iptek.

Fungsi mata pelajaran matematika di SMA adalah sebagai wahana untuk:

1) Meningkatkan ketajaman penalaran peserta didik yang dapat membantu memperjelas dan menyelesaikan permasalahan dalam kehidupan sehari - hari.

2) Meningkatkan kemampuan berkomunikasi dengan menggunakan bilangan dan simbol - simbol.

Tujuan pendidikan matematika di SMA agar peserta didik memiliki kemampuan yang dapat dialihgunakan, dengan memiliki kemampuan matematika peserta didik diharapkan dapat mengalihgunakan kemampuan tersebut dalam menghadapi masalah - masalah dalam berbagai bidang pelajaran atau kehidupan. Kemampuan bernalar, kemampuan memilih strategi yang cocok dengan permasalahannya maupun kemampuan menerima dan mengemukakan suatu informasi secara tepat dan cermat merupakan kemampuan umum yang dapat digunakan dalam berbagai bidang.

Dari penjabaran di atas matematika adalah ilmu yang mempelajari semua hal yang berkaitan dengan penalaran, yang menjadi dasar dari banyak ilmu, selain itu matematika pada tingkat rendah terdapat ilmu hitung, ilmu ukur, dan aljabar.

Manusia sebagai makhluk individu maupun sosial membutuhkan pengetahuan untuk berelasi dengan yang lain. Kebutuhan terhadap pengetahuan akan meningkatkan harga diri sebagai manusia. Pengetahuan yang dimiliki oleh manusia diperoleh melalui belajar secara mandiri atau berkelompok. Pengetahuan akan mengubah manusia dalam bertindak dan bertingkah laku.

Menurut Bruner (dalam Daryanto 2012: 160) proses belajar dapat dibedakan dalam 3 fase, yaitu:

1) Fase Informasi

Dalam tiap pelajaran untuk memperoleh sejumlah informasi, ada yang menambah pengetahuan yang telah dimiliki, ada yang memperdalamnya, dan ada pula yang bertentangan dengan apa yang telah diketahui sebelumnya.

2) Fase Transformasi 
Informasi harus dianalisis, diubah, atau ditranformasikan ke dalam bentuk yang lebih abstrak atau konseptual agar dapat digunakan untuk hal - hal yang lebih luas.

\section{3) Fase Evaluasi}

Fase ini adalah fase di mana dapat menilai sejauh mana pengetahuan yang diperoleh dan ditransformasikan itu dapat dimanfaatkan untuk memahami gejala - gejala lain

Jadi belajar adalah suatu kegiatan sadar yang dilakukan seseorang sehingga informasi baru yang diterima akan dihubungkan dengan pengalaman sebelumnya di mana otak akan bekerja menjadi lebih efisien.

Proses pembelajaran sebagai suatu sistem yang terdiri dari komponen guru, peserta didik, materi pembelajaran, dan lingkungan belajar yang saling berinteraksi satu sama lain dalam usaha untuk mencapai tujuan. Setelah mengikuti proses pembelajaran seorang peserta didik dapat mengetahui kemampuan hasil belajarnya melalui tes yang dilakukan oleh guru.

Poerwadarminta (1997: 895) mengartikan prestasi sebagai hasil yang telah dicapai dari apa yang telah dilakukan atau dikerjakan, sedangkan prestasi belajar adalah hasil yang telah dicapai melalui penguasaan pengetahuan atau ketrampilan yang dikemabangkan melalui mata pelajaran.

Menurut Slameto (2010: 23), prestasi belajar adalah penilaian hasil usaha kegiatan hasil belajar yang dinyatakan dengan simbol, angka, huruf, maupun hal yang dapat mencerminkan hasil yang sudah dicapai oleh setiap peserta didik dalam periode tertentu.

Dari uraian tersebut dapat disimpulkan bahwa prestasi belajar adalah hasil yang dicapai peserta didik setelah melalui proses belajar yang ditunjukkan dengan nilai raport.

Hal penting dalam pembelajaran matematika adalah proses dengan tidak melupakan tujuan. Proses ini lebih ditekankan pada proses belajar matematika seseorang. Tujuan yang paling utama dalam pembelajaran matematika adalah mengatur jalan pikiran untuk memecahkan masalah bukan hanya menguasai konsep dan perhitungan walaupun sebagian besar belajar matematika adalah belajar 
konsep, struktur, ketrampilan menghitung, dan menghubungkan konsep - konsep tersebut.

Dari uraian pengertian matematika, pengertian belajar, dan pengertian prestasi belajar tersebut dapat disimpulkan bahwa prestasi belajar matematika adalah hasil ketrampilan yang didapat dari seorang peserta didik setelah proses belajar matematika yang dinyatakan dalam bentuk simbol, angka, dan huruf. Bentuk - bentuk simbol, angka, maupun huruf mewakili suatu nilai yang diperoleh seorang peserta didik dalam prestasi belajar matematika.

Menurut Permendikbud No. 23 tahun 2017, peserta didik adalah anggota masyarakat yang berusaha mengembangkan potensi diri melalui proses pembelajaran yang tersedia pada jalur, jenjang, dan jenis pendidikan tertentu.

Sesuai dengan hasil penelitian yang telah ada, antara lain yang telah dilakukan oleh Nurul (2018), bahwa terdapat hubungan yang signifikan anatara penerapan full day school dengan prestasi belajar PAI selain itu $45,1 \%$ variabel prestasi belajar PAI peserta didik dipengaruhi oleh sistem full day school, sisanya sebesar 54,9\% dipengaruhi oleh variabel lain.

Penelitian yang dilakukan Dina (2018), menyimpulkan bahwa terdapat pengaruh antara program full day school terhadap prestasi belajar peserta didik. Hasil penelitian juga menunjukkan terdapat pengaruh positif antara program full day school terhadap prestasi belajar peserta didik sebesar 6,6\%.

Titik berat dari penelitian Yudefrizal (2017) adalah penerapan sistem full day school ini berdampak pada peserta didik, yang dapat dilihat dari dua sudut pandang yaitu dampak positif dan negatif. Dampak positifnya adalah pengalaman belajar lebih, mengurangi resiko kenakalan remaja, lebih efektif memberikan mata pelajaran, sedangkan dampak negatifnya adalah adanya perasaan jenuh, penurunan daya pencermatan observasi guru, perlakuan guru di kelas dan meinimnya kerja sama guru dengan peserta didik.

Triyono (2018), dalam penelitiannya menyimpulkan bahwa aspek psikologis guru pada indikator kondisi sekolah adalah 88\%, hubungan sosial adalah $83 \%$, pemenuhan diri adalah $73 \%$, dan kondisi kesehatan adalah $86 \%$. Sedangkan tinjauan dari aspek akademis guru pada indikator landasan filosofis adalah $80 \%$ dan landasan pendagogis adalah $84 \%$. Tinjauan dari aspek psikologis siswa pada 
indikator kondisi sekolah adalah $76 \%$, hubungan sosial adalah $72 \%$, pemenuhan diri adalah 69\%, dan kondisi kesehatan adalah 76\%. Sedangkan tinjauan dari aspek akademis siswa pada indikator landasan filosofis adalah $75 \%$ dan landasan pendagogis adalah 75\%. Sehingga dapat dikatakan bahwa penerapan 5 days school di SMA Negeri 1 Bae Kudus sudah efektif dari aspek psikolgis dan akademis.

Beberapa penelitian lain menunjukkan hasil yang berbeda, misalnya peneltian yang dilakukan oleh Hasan (2006) bahwa penerapan kebijakan ini menimbulkan rasa bosan dan jenuh bagi peserta didik sehingga perlu kesiapan psikologis maupun intelektual. Penelitian senada juga dilakukan oleh Holm (2014) menyimpulkan bahwa pelasanaan kebijakan ini menghilangkan budaya dan lingusik keluarga.

Pembelajaran 5 hari sekolah adalah faktor yang berpengaruh terhadap prestasi belajar matematika peserta didik, karena peserta didik mempunyai waktu lebih banyak untuk memahami materi. Sehingga dimungkinkan bahwa pelaksanaan pembelajaran 5 hari sekolah di SMA Negeri 1 Bae Kudus prestasi belajar matematika lebih baik dari pada pembelajaran 6 hari sekolah.

\section{KESIMPULAN}

Berdasarkan kajian teori dan dikdukung dengan perhitungan statistik serta mengacu pada rumusan masalah, maka dapat disimpulkan sebagai berikut:

a. Pada pembelajaran 5 hari sekolah menghasilkan prestasi belajar matematika lebih baik daripada pembelajaran 6 hari sekolah, berdasarkan hasil perhitungan nilai $\mathrm{t}_{\mathrm{obs}}=-17,429$ dan $\mathrm{DK}=\{\mathrm{t} \mid \mathrm{t}<-1,656$ atau $\mathrm{t}>1,656\}$, ternyata $\mathrm{t}_{\mathrm{obs}} \in \mathrm{DK}$ sehingga $\mathrm{H}_{0}$ ditolak. Hal ini dapat dikatakan bahwa terdapat pengaruh pembelajaran 5 hari sekolah terhadap prestasi belajar matematika peserta didik.

b. Berdasarkan hasil perhitungan koefisien determinasi $\left(\mathrm{r}^{2}\right)$ sebesar 0,111 menunjukkan bahwa besarnya pengaruh 5 hari sekolah terhadap prestasi belajar matematika sebesar 11,1\%. Dengan koefisien korelasi (r) sebesar 0,334 yang berkategori lemah, artinya pembelajaran 5 hari sekolah bukan satu - satunya faktor yang menentukan prestasi belajar matematika peserta didik melainkan adanya faktor - faktor lain yang tidak ada di dalam penelitian ini. 
Berdasarkan hasil penelitian dan kesimpulan yang diperoleh, bahwa untuk meningkatkan prestasi belajar matematika peserta didik dapat dilakukan melalui pembelajaran 5 hari sekolah, meskipun pembelajaran 5 hari sekolah memberikan pengaruh yang lemah dan bukan satu - satunya faktor yang menentukan prestasi belajar matematika peserta didik.

\section{DAFTAR PUSTAKA}

Budiyono. 2009. Statistik Untuk Penelitian Edisi ke 2. Surakarta: Sebelas Maret University Press.

Dina Melan Sari. 2018. Pengaruh Full Day School terhadap Prestasi Belajar Siswa. Bandar Lampung: Skripsi FISIP Universitas Lampung (Unpublished).

Hasan. 2006. Full Day School (Model Alternatif Pembelajaran Bahasa Asing). www.ejournal.stainpamekasan.ac.id/index.php/tadris/article/view/194/15.

Holm. 2014. Parental Perspectives On Danish Full-Day Schools For Ethnicminority Students. International Journal About Parents In Education 2014, Vol 8 No 126 $-33$

Nurul Fauziyatul Iffa. 2018. Pengaruh Sistem Full Day School Terhadap Prestasi Belajar PAI Siswa Di MI YPPI 1945 Babat Lamongan. Surabaya: Skripsi Fakultas Tarbiyah dan Keguruan UIN Sunan Ampel Surabaya. (Unpublished)

Poerwadarminta. 1997. Kamus Besar Bahasa Indonesia. Jakarta : Balai Pustaka Slameto 2010

Slameto. 2010. Belajar dan Faktor-faktor yang Mempengaruhinya. Jakarta: Rineka Cipta.

Triyono. 2018. Menelisik Persepsi Civitas Akademik terhadap Pelaksanaan 5 Days School Bagi SMA Sederajat di Jawa Tengah Tinjauan Psikologis dan Akademis (Studi di SMA Negeri 1 Bae Kudus). Semarang: Lapaoran Hasil PKM Penelitian UNNES. (Unpublished)

Yudefrizal. 2017. Dampak Sistem Full Day School terhadap Prestasi Belajar Pendidikan Agama Islam Siswa Kelas VIII SMP IT Abu Bakar Yogyakarta. Yogyakarta: Skripsi Fakultas Ilmu Tarbiyah dan Keguruan UIN Sunan Kalijaga. (Unpublished)

Sugiyono. 2014. Metode Penelitian Kuantitatif, Kualitatif, dan Kombinasi (Mixed. Methods). Bandung: Alfabeta. 